\title{
Control of Glycolytic Flux by AMPK and p53-mediated Signaling Pathways in Tumor Cells Grown at Low pH
}

\author{
D. B. Leeper \\ Thomas Jefferson University \\ E. E. Mendoza \\ University of Arizona \\ J. Caro \\ Thomas Jefferson University \\ R. Burd \\ University of Arizona
}

Follow this and additional works at: https://jdc.jefferson.edu/bodinejournal

Part of the Oncology Commons

Let us know how access to this document benefits you

\section{Recommended Citation}

Leeper, D. B.; Mendoza, E. E.; Caro, J.; and Burd, R. (2010) "Control of Glycolytic Flux by AMPK and p53-mediated Signaling Pathways in Tumor Cells Grown at Low pH," Bodine Journal: Vol. 3 : Iss. 1 , Article 20.

DOI: https://doi.org/10.29046/TBJ.003.1.019

Available at: https://jdc.jefferson.edu/bodinejournal/vol3/iss1/20

This Article is brought to you for free and open access by the Jefferson Digital Commons. The Jefferson Digital Commons is a service of Thomas Jefferson University's Center for Teaching and Learning (CTL). The Commons is a showcase for Jefferson books and journals, peer-reviewed scholarly publications, unique historical collections from the University archives, and teaching tools. The Jefferson Digital Commons allows researchers and interested readers anywhere in the world to learn about and keep up to date with Jefferson scholarship. This article has been accepted for inclusion in Bodine Journal by an authorized administrator of the Jefferson Digital Commons. For more information, please contact: JeffersonDigitalCommons@jefferson.edu. 


\title{
Control of Glycolytic Flux by AMPK and p53-mediated Signaling Pathways in Tumor Cells Grown at Low pH
}

\author{
Leeper,D.B., ${ }^{1}$ Mendoza, E.E., ${ }^{2}$ Caro, J., ${ }^{3}$ Burd, R. ${ }^{2}$ \\ ${ }^{1}$ Department of Radiation Oncology, ${ }^{3}$ Department of Hematology and Oncology, Thomas Jefferson University, Philadelphia, PA \\ ${ }^{2}$ Department of Nutritional Sciences, University of Arizona, Tucson, AZ
}

\section{Introduction}

Tumor cells grow in nutrient and oxygen deprived microenvironments and adapt to the suboptimal growth conditions by altering metabolic pathways. This adaptation process characteristically results in a tumor phenotype that displays upregulated Hif- $1 \alpha$ anaerobic glycolysis, chronic acidification, reduced rate of overall protein synthesis, lower rate of cell proliferation and aggressive invasive characteristics. Most transplantable tumors exhibit a pHe of 6.77.0; the DB-1 melanoma xenografts used here have a $\mathrm{pHe}=6.7$. Understanding tumor cell reaction to the microenvironment is a critical factor in predicting the tumor response to radiotherapy. The glucose regulatory molecule, 6-Phosphofructo-2-Kinase/Fructose-2,6Biphosphatase Isoform-3 (PFKFB3), is a bifunctional enzyme central to glycolytic flux and downstream of the metabolic stress sensor AMP-activated protein kinase (AMPK), which we show activates an isoform of phosphofructokinase (PFK-2).

\section{Methods}

All techniques including the growth of the early passage DB-1 human melanoma and the U87 human glioma cells were standard and have been published.

\section{Results}

As hypothesized, our results demonstrated that growth at chronic pH 6.7 in air induced AMPK activation resulting in the upregulation of PFKFB3 and p53 and the downregulation of mammalian TargetOf-Rapamycin (mTOR) in both human tumor cell lines. Conversely, inhibition of AMPK resulted in downregulation of PFKFB3 and inhibition of glycolysis. When PFKFB3 was transfected and overexpressed in DB-1 melanoma cells growing at $\mathrm{pH} 7.3$, it induced a high rate of glycolysis and inhibited oxygen consumption, which could lead to tumor acidification and oxygenation. By contrast, cells growing at low $\mathrm{pH}$ did not display an increased rate of glycolysis after PFKFB3 expression because the level of the TP53-induced Glycolysis and Apoptosis Regulator (TIGAR) was increased. Cells growing at low $\mathrm{pH}$ also were resistant to radiation-induced apoptosis despite upregulation of $\mathrm{p} 53$. This was partially explained by the expression of the anti-apoptotic proteins, Bcl-2 and Bax;
TIGAR's ability to reduce lactate production; and downregulation of mTOR. Conversely, growth at low $\mathrm{pH}$ blocked GSH production and reduced bioreduction.

\section{Conclusion}

These results indicate that growth at tumor-like low $\mathrm{pH}$ activates AMPK and PFKFB3 and induces a high glycolytic and apoptotic potential that is countered by TIGAR and anti-apoptotic proteins, respectively. Alterations in these pathways lead to predictable alterations in lactate and oxygen levels, mTOR, GSH and redox state, and response to radiation. The control of glycolysis can thus alter acidification, oxygenation and state of bioreduction and modify tumor cell death pathways. These metabolic pathways that respond to the microenvironment require incorporation in radiation treatment strategies.

Supported in part by NIH P01 CA36690 and K22 DE16096. 